\title{
Traditional Development Theories have failed to Address the Needs of the majority of People at Grassroots Levels with Reference to GAD
}

\author{
Dr. Reem Abuiyada \\ Social Sciences Department \\ Dhofar University \\ Salalah, Sultanate of Oman
}

\begin{abstract}
A multitude of meanings is attached to the idea of development; the term is complex. It is a bout building active and sustainable communities based on social justice and mutual respect. It is about changing power structures to reduce barriers that prevent people from participating in the issues that affect their lives. Sometime the implementation of the development programs does not consider the real needs of the grassroots. This paper presents the relationship between development theories and the exact needs of the grassroots. It also devoted particular attention to gender and development as the women have little power at all the levels. They need to be more involved in non-domestic or public sector. For development to be effective there is a need of equity consideration between empowerment and growth.
\end{abstract}

Keywords: Development, grassroots, theories, empowerment, and gender.

\section{Introduction}

Development theories do not provide a comprehensive explanation of development as 'development'. For example, development does not refer to one particular perspective on social, political and economic betterment. Instead, it is a hybrid term for a myriad of strategies adopted for socio-economic and environment transformation from current states to desired ones (Pearson, 1992).

Most development programmes are designed and implemented without giving attention to the exact needs of the grassroots level.

The aim of this paper is to consider the relationship between development theories and the grassroots. It defines the meaning of development and describes development theories with great attention to the grassroots. Finally, it discusses gender and development.

\section{Definition of Development}

The term "development" has various meanings to different people and can be explained in different contexts. For example, the development needs of a starving population must be different from those where there is sufficient nutrition (Matowanyka, 1991). Development has often been confused with "economic growth as measured solely in terms of annual increases in pre-capita income or gross national product, regardless of its distribution and the degree of people's participation in effective growth" (Mahmoud, 1991). Seers (1972) asserted that "development means the conditions for realisation of the human personality. Its evaluation must therefore take into account three linked criteria: where there has been a reduction in (1) poverty, (2) unemployment, (3) inequality".

According to Pearson (1992), development involves "An improvement qualitative, quantitative or both - in the use of available resources". He also asserts that development does not refer to one particular perspective on social, political and economic betterment. Instead, it is a hybrid term for a myriad of strategies adopted for socioeconomic and environment transformation from current states to desired ones.

\section{Theorising Development}

\subsection{Modernisation; Development through Economic Growth}

Development theory has until recently been dominated by theories and models derived from the experiences of western economic history. The emergence of capitalism and the advance of the industrial revolution gave a distinctive form to western development thinking. 
Economic growth became synonymous with progress and a higher level of civilisation, and it was seen as a natural process which could be nourished through the application of correct and timely inputs. Likewise, it could be impeded by bad conditions, but once these constraints were removed, the process would continue (Burkey, 1993).

Development in the third world was expected to be an imitative process in which the less developed countries gradually assumed the qualities of the industrial nations, by increasing gross levels of savings and investments (both internal and external, private and state) until the economy reached a take off point into self sustaining development. Therefore, an appropriate combination of domestic savings, international investment and international aid would provide the fuel to drive the process through stages of growth which would ultimately bring the benefits of modernisation to the entire population. In this model, political and social development would follow, and were dependent upon, economic growth (Burkey, 1993).

However, critics argued that in many countries what was taking place was growth without development but with increasing poverty, which in the 1980s led to negative growth and the debt crisis (Burkey, 1993). Following Seers (1972) they argued that development should be seen as a progress towards complex goals such as the elimination of poverty, the provision of employment, the reduction of inequality and the guarantee of human rights. The changed definition had sub definitions such as redistribution with growth, the basic needs approach and integrated rural development.

\subsection{Dependency Theory of Underdevelopment:}

Neo-Marxists did not dispute this changed emphasis on the meaning of development (though questioning whether it was achievable). They, too, rejected the modernization school, but looked to historically-grounded analysis of political economy (Hulme, 1997). One of the main theoretical positions this generated was dependency theory.

The dependency theory of underdevelopment questioned the mutual benefits of international trade and development asserted by European and American proponents of modernisation and growth theories. They undoubtedly lead to North America economic dominance in Latin American countries, and were strongly involved in the development of the neo-Marxist thinking (Burkey, 1993).

The theory maintained that the central nations benefited from trade, whereas the peripheral nations suffered Latin America nations were dualistic societies consisting of a proportionally large traditional agrarian society and a small, modern, urbanised society. The urbanised centres were themselves developing at the expense of the rural peripheries. The unequal relationships between the centres and the peripheries led to the development of the former and to the underdevelopment of the latter (Burkey, 1993)

The central argument of dependency theory is that socio-economic dependency - neo colonialism - generates underdevelopment. Some of the reasons elaborated for this "development of underdevelopment" were: long term trends in the terms of trade which favoured the centres; the balance of economic and political power was at the centres; and finance and technology were controlled by the centres. In order to reverse this situation, the dependency doctrine stressed industrialisation by import substitution, planning and state interventionism in general, and regional integration. However, industrialization through import substitution was difficult in practice because of the small size of internal markets and the need to import technology and other factors of production, especially petroleum products, which required large amounts of foreign exchange. In addition, planning and state intervention created, in many cases, paralysing bottlenecks and inefficiencies. Finally, regional integration has proved to be agonisingly slow or non-existent (Burkey, 1993).

\subsection{Global Interdependence:}

The response to the decline of the dependency theory was not a simple return to classical modernisation and development through growth, nut rather towards attempts to define a more universal approach to development incorporating the complex relationship between both the central and peripheral development, in order words theories stressing global interdependence through globalised markets and trade.

Through the 1970s, global interdependence became more and more obvious and resulted in a proliferation economic order favouring the developing nations, and proposing a massive transfer of financial resources to the poor countries. Ironcally, in the 1980s the world saw the result of just such a massive resource transfer of dollars to selected third world countries through western commercial banks, bilateral and international lending institutions. Rather than leading to balanced economic development in these countries, this transfer has developed into the world debt crisis which has yet to be resolved (Friedman, 1992).

116 
Two responses can be identified. Neo-liberal 'counter-revolutionaries' (Toy in Turner and Hulme, 1997) advocate policies restricting state intervention in the economy and society. They point to inefficiency and ineffectiveness in planned development and celebrate the optimal resource allocation which reliance on the market allegedly provides. For some of the counter-revolutionaries, the third world is in fact the creation of foreign aid.

The second response in more diffuse. It recognises the realities of power, by which development has often degenerated into rhetoric in which admirable official goals, such as the satisfaction of basic needs, job provision and better social services, are supplanted by operational goals which focus on debt-servicing, crisis management and defence of privilege. It recognises that any definition will be value-laden, a product of personal preference, and that there will never be universal agreement on a single meaning (Burkey, 1993).

\section{Grassroots and Development}

Development has long been viewed as enhancing the capacity of grassroots level of people to influence their future for the better. It means doing what needs to be done to expand and optimise resources on the path of Changing (Mathur, 1985). Saes and Tason (1981) stressed the importance of empowerment as a development tool. Empowerment, they asserted, gives people the opportunity not only to be agents for development but also to receive its benefits. In this regard, empowerment should be integrated along with growth and equity considerations for development to be effective.

Many programmes in developing countries were planned comprehensively, designed in great detail at the outset, and managed through centrally controlled systems and procedures of administration. Many of these programmes fell short of achieving their intended goals. Further, many implementing organisations had defects in terms of their effectiveness and structural or operational proficiencies (Bryant, 1992).

The meeting of the basic needs of the poor people became an important element in alternative development strategies. The basic needs include several elements (Friedman, 1993). First, they include certain minimum requirements of a family for a private consumption. Adequate food, shelter and clothing are included, as is certain household equipment. Second, they include essential services provided by and for the community at large, such as safe drinking water, sanitation, public transport, and health and educational facilities. The discussions on meeting basic needs have been useful in creating awareness of the fact that growth does not necessarily benefit the poor, but the question of how these needs can be met has still not been resolved.

\section{Gender and development:}

Development planners and policy makers are becoming more aware of the nature and impact of gender, women's empowerment and their participation with men in shaping the decision-making process to improve rural livelihoods and reach sustainable development.

Social scientists differentiate between 'sex' as a biological term that describes biological and physical differences between men and women, and 'gender' as a sociological term that describes these differences as being 'socially and culturally constructed'. These differences are reflected in: roles, responsibilities, access to resources, constraints, opportunities, needs and perceptions held by both sexes (Barnett, 1988, pp.158-160; Foster-Carter, 1985).

Women have particular needs that differ from those of men, because of their usually subordinate position to men. There are two types of needs: practical and strategic. Practical needs include improving their health and services for their families, increasing their income and reducing their workload. Strategic needs, on the other hand, include improving their education opportunities, gaining equal opportunity for employment and ownership, and increasing their participation in decision making (Moser, 1993. Quoted in Pearson, 2000, p.388; Foster-Carter, 1985).

It is interesting to note that a gender-based debate began to take shape in the 1970s with the publication of the Danish development analyst, Ester Boserup's book Women's Role in Economic Development. She "helped to put women and development into an international context by clarifying both the human dimension of economic development and the policy issues raised by the development projects undertaken in the 1960s" (Charlton, 1984, p.1). 
From there on, many development agencies began to incorporate women's needs in their projects. The position of 'women in development' was also strengthened by having a UN Decade for Women (1975-1985), and holding many international conferences targeting women like the International Women's Conference in Nairobi (1985), and Beijing (1995), the International Conference on Population and Development (ICPD), Cairo 1994, and the Copenhagen Summit on Population and Social Development (1995), Habitat (1996).

During this period, many studies focusing on women and gender relations were undertaken. The Women in Development Office of the US Agency for International Development (WID/USAID) financed a wide variety of studies related to development, women and using appropriate technology for female farmers (Charlton, 1984, p.39). Different approaches to gender were developed throughout this period. One approach to which Boserup's work contributed is Women in Development (WID) focusing on addressing women's needs by integrating them into development projects (Charlton, 1984, p.39; Braidotti, et al., 1994, p.79).

One of the GAD variations is the well-known 'efficiency approach', which stresses the importance of active participation of women in projects to become effective and efficient. 'Empowerment' is another approach, focusing on removing social and institutional barriers to reach structural change in gender relations as well as economic growth (World Bank, 2001). These approaches, especially empowerment, with its emphasis on structural change, illustrate that gender has a very important role to play in the initiation and promotion of sustainable development, especially in rural areas.

Throughout the world's rural areas, both men and women are heavily involved in agricultural production and other economic activities for household consumption and for sale. Women's role in agriculture differs greatly from one area to the other. In Sub-Saharan Africa, for example, rural women are responsible for 60-80 percent of the agricultural labour for food production, its storage, transport and sale. This is coupled with their other reproductive activities, like childbearing, rearing, preparing food, gathering fuel and water. Women could spend up to 16 hours a day doing these domestic and farm tasks (Moser, 1993).

Despite this tremendous effort, most of these rural women are not directly remunerated for their work or reap little benefit from their labour (Afsher, 1991; Moser, 1993). Focusing on rural women in Southern Africa (Zambia, Zimbabwe and Malawi) in relation to their access to and control of resources, Anne Akeroyd (1991) argues that although these women have de facto responsibilities as being female-heads of households, they lack de jure control over decision-making and the allocation of resources. For example, a married woman may need her husband's approval before buying items either for investment or consumption, undertaking paid work, or making gifts or loans to her kin (p.148).

There are many gender discriminatory practices and inequalities exemplified in lower literacy rates of women, limited access to productive resources (e.g., land, credits, technology); social services (e.g., health, legal services); and limited power in the decision-making processes. Various interpretations have been given to these discriminatory practices against women. One explanation by the reductionist approach limits it to physical differences. Other approaches focus on the political, cultural and ideological explanations (Barnett, 1988).

Politically speaking, women have little or no formal institutionalised power at local, national or international levels. The greater their empowerment and involvement in non-domestic or public, the greater their status and influence (Charlton, 1984). This, however, should be coupled with an improvement of men's position and maintaining equilibrium between the power of both men and women to avoid potential conflict. The case of empowered women in rural Vietnam is a vivid example of how gender conflicts could arise by changing women's positions (White, 1987).

From a cultural and ideological point of view, Afsher (1991) argues that there are ideological misconceptions related to women's productive role that deny them the right to work and idealise their image as 'home-based, child-rearing women' (p.9). These misconceptions also aim at protecting their honour and dignity (Afsher, 1987), pp.4-5). Development could take place "only if and when it addresses the double-burdens of production and reproduction carried by women” (Afsher, 191, p.2). Once women's productive roles are accepted, it becomes easier to begin the long process of ideological change, empower women and eliminate their subordination. 


\section{Conclusion}

The term "development" has various meaning to different people and can be explained in different contexts. Development should be seen as a progress towards complex goals such as the elimination of poverty, the provision of employment, the reduction of inequality and the guarantee of human rights. The changed definition had sub definitions such as redistribution with growth, the basic needs approach and integrated rural development. The response to the decline of the dependency theory was not a simple return to classical modernisation and development through growth, but rather towards attempts to define a more universal approach to development incorporating the complex relationship between both central and peripheral development, in order words theories stressing global interdependence through globalised markets and trade.

Empowerment should give people the opportunity not only to be agents for development but also to receive its benefits. In this regard, empowerment should be integrated along with growth and equity considerations for development to be effective.

Women have little or no formal institutionalised power at local, national or international levels. The greater their empowerment and involvement in non-domestic or public spheres, the greater their status and influence.

\section{Bibliography}

Afsher, H. (Ed.). (1987). Women, State and Ideology: Studies from Africa and Asia. London: Macmillan Press. (1991). Women, Development and Survival in the Third World. London: Longman.

Akeroyd, A. (1991). 'Gender, Food Production and Property Rights: Constraints on Women Farmers in Southern Africa', in Afsher, H. (ed). Women, Development and Survival in the Third World. London: Longman.

Barkey, S. (1993) People First: A Guide to Self-reliance, Participatory Rural Development. Zed books.

Barnett, T. (1988). Sociology and Development. London: Routledge.

Braidotti, R. et al. (1994). Women, the Environment and Sustainable Development: Towards a Theoretical Synthesis. London: Zed Books.

Charlton, S. (1984). Women in Third World Development. London: Westview Press.

Friedman, J. (1992) Empowerment; The Politics of Alternative Development. Oxford, Blackwell Press.

Foster-Carter, A. (1985). The Sociology of Development. Lancashire: Causeway Books.

Mahmoud, F. (1991) “African Women and Feminists Schools of Thought”. In Suliman, M. (ed.)

Moser, C. (1993). Gender Planning and Development: Theory, Practice and Training. $\quad$ London: Routledge.

Pearson, R. (2000). 'Rethinking Gender Matters in Development', in Allen, T. \& Thomas, A. (eds.). Poverty and Development into the $21^{\text {st }}$ Century. Oxford: Oxford University Press.

Turner and Hulme (1997) Governance, Administration and Development; Make the State Work.. Houndmills, Basingstoke Hampshire: Macmillan Press Ltd

White, C. (1987). 'State, Culture and Gender: Continuity and Change in Women's Position in Rural Vietnam', in Afsher, H. (ed.). Women, State and Ideology: $\quad$ Studies from Africa and Asia. London: Macmillan Press.

World Bank (2001).World Development Report 2000/2001: Attacking Poverty Oxford: Oxford University Press. 